\title{
Recent Research on the Australian Monsoon
}

\author{
By M.J. Manton and J.L. McBride \\ Bureau of Meteorology Research Centre, Melbourne, Australia \\ (Manuscript received 26 August 1991, in revised form 14 October 1991)
}

\begin{abstract}
Owing to the data flowing from a number of observational programs, there has been over the last few years a sustained research effort on improving our understanding of the Australian monsoon. This paper discusses the findings of that research, including results on the large-scale structure of the monsoon, interannual variability, onset, intraseasonal variability, and mesoscale structure. Although there has been significant progress, much work remains to be done on relating regional aspects of the monsoon to the general tropical circulation.
\end{abstract}

\section{Introduction}

The purpose of this paper is to review the results of research carried out over the last few years on the monsoon that occurs over northern Australia in the southern hemisphere summer. Although the monsoonal nature of tropical Australia has been recognized for the last hundred years (Hunt et al., 1913), the first quantitative studies of the Australian monsoon were undertaken in the early 1960 s by Berson (1961) and Troup (1961). They showed that the summer rainfall in northern Australia has a clear monsoonal character, with low-level westerlies extending from the equator to about 15 degrees south. It is similar to the Indian monsoon to the extent that the onset is sudden over a wide region and that it exhibits intraseasonal active-break periods.

Following those initial studies there was little work on the Australian monsoon until the First GARP Global Experiment (FGGE) in 1978-79 provided a new source of relevant data and so a new impetus for research. A number of diagnostic analyses were carried out in the early 1980s using the FGGE data (for example, Davidson et al. (1983) and Murakami and Sumi (1982)), and that work is reviewed by McBride (1987). One result of those studies was the recognition of differences between the Australian and Indian monsoons. In particular, McBride shows that the synoptic-scale convective regions in the Australian monsoon tend to move longitudinally (either eastward or westward), while Sikka and Gadgil (1980) find that convective activity in the Indian monsoon is associated with northward movements of the Inter-Tropical Convergence Zone (ITCZ).

Climatological studies in the early 1980s showed a

(c)1992, Meteorological Society of Japan weak relationship between interannual fluctuations in the Southern Oscillation and some aspects of the Australian monsoon, such as the time of onset (Nicholls, 1984). However, strong connections were found between intraseasonal variations, such as the active-break periods and tropical cyclones, and the 40-50 day oscillation (McBride, 1987).

Over the last six years there has been a number of major field studies centred on Darwin in northern Australia which have produced data on scales from the synoptic down to the mesoscale. These data, together with the enhancement of satellite data from the Japanese Geostationary Meteorological Satellite (GMS), have supported significant diagnostic and numerical modelling research on aspects of the Australian summer monsoon, particularly the monsoon onset and the mesoscale structure of convection.

The first set of field projects was held simultaneously in 1986-87. They were the Australian Monsoon Experiment (AMEX) coordinated by BMRC and providing high-density synoptic and mesoscale data over northern Australia (McBride and Holland, 1989), the Equatorial Mesoscale Experiment (EMEX) sponsored by NOAA and NSF and focusing on aircraft observations of cloud clusters (Webster and Houze, 1991), and the Stratosphere-Troposphere Exchange Project (STEP) sponsored by NASA and concentrating on high-altitude aircraft observations of deep convection. These complementary projects extended for 36 days from 10 January 1987, and they collected unique data on the monsoon onset as well as two active-break cycles during the monsoon season.

The success of AMEX/EMEX/STEP demonstrated that detailed observations of the Australian monsoon lead to worthwhile results and that Darwin is one of the few tropical sites in the world which 
can provide the logistical support needed for largescale field programs. Thus a four-year program was commenced in 1987 in which the Australian Bureau of Meteorology operated the NOAA/TOGA Doppler radar in Darwin to provide data to support the NASA Tropical Rainfall Measuring Mission (TRMM). This collaborative program between NASA, NOAA and BMRC has led to the collection of continuous rainfall data over the wet seasons from $1987-88$ to $1990-91$ and to a series of specific field studies on the convective storms that develop over the land and sea around Darwin (Keenan et al., 1988).

\section{Large-scale structure of the monsoon}

Analysis of satellite data confirms that the Australian monsoon does not occur in regional isolation, rather it is the eastward and southward excursion of the seasonal evolution of a planetary-scale monsoon phenomenon that extends across the maritime continent. This feature is seen particularly from satellite infrared imagery, i.e. outgoing longwave radiation (OLR), that shows the translation of the monthlyaverage peak in convection from India in July to north Australia in January (Meehl, 1987).

Until the mid-1980s, the FGGE data set was the main source of information on the large-scale structure of the monsoon. However, detailed GMS imagery and numerical weather prediction analyses can now be used confidently for such studies. Taking a three-year composite of Australian operational tropical numerical analyses, Hendon et al. (1989) show meridional movement of the monsoon on the seasonal time scale over Australian longitudes. They find that the low-level westerlies first move into the southern hemisphere in November and advance to 15 degrees south by January.

The relationship between monsoon rainfall (or OLR) and the zonal wind is demonstrated by Holland (1986), who analyses 32 years of wind data at Darwin. He finds that the seasonal-mean rainfall averaged over northern Australia is strongly correlated with the zonal wind anomalies at both low ( 850 $\mathrm{hPa})$ and upper $(150 \mathrm{hPa})$ levels during the monsoon season at Darwin, the sign of the correlations being such that high seasonal rainfall corresponds to low-level westerly anomalies and upper-level easterly anomalies, with the zero-crossing at about $400 \mathrm{hPa}$.

Prior to AMEX, analyses of the monsoon structure had to be largely inferred from single-station radiosonde data, e.g. from Darwin. The AMEX was designed to provide for the first time a highresolution data set for examination of the monsoon structure across northern Australia. (We note that there has not been a similar study of the lowlatitude structure of the southern-hemisphere monsoon over Indonesia.) There were 14 upper-air stations across northern Australia taking 6-hourly ob- servations during the 36-day period of AMEX. Time height sections of zonal wind at several stations (Gunn et al., 1989) show that the monsoon flow has substantial longitudinal coherence. Moreover the active bursts of monsoon westerlies extend from the surface to between 400 and $200 \mathrm{hPa}$.

Thus the active monsoon bursts have a different structure from the seasonal-mean monsoon circulation, which in monthly average data at Darwin shows westerlies only up to about $700 \mathrm{hPa}$ (Maher and Lee, 1977). This result implies that definitions of onset and active-break times based on "deep westerly flow" may be better related to large-scale rainfall than the current "low-level westerly" definitions of Troup (1961) and subsequent authors.

The average position of the monsoon shear line throughout AMEX is found to run through the upper-air observing network (Gunn et al., 1989). Thus the meridional structure of the monsoon is well defined from the data. Soundings north of the shear line are moist and in a low-level northwesterly flow, while soundings to the south are relatively dry in the low-level southeasterly trade winds. Similarly, the distribution of total rainfall during AMEX has a strong meridional gradient, dropping from $800 \mathrm{~mm}$ in the north to less than $100 \mathrm{~mm}$ south of the monsoon trough.

Casual observations, such as the AMEX result that the monsoon shear line tends to lie over north Australia, suggest that the dynamics of the Australian monsoon are consistent with the classical model of a planetary-scale sea-breeze associated with seasonal heating of the continent. This assumption is supported by a numerical modelling study of Kiladis et al. (1989) who show that the monsoon structure does not occur if the Australian land mass is omitted from a general circulation model. However, their results are not altogether convincing because the monsoon strength in their control run is very weak. Further work on the roles of the Australian and Indonesian land masses in the dynamics of the seasonal cycle of the monsoon is clearly justified.

Recent studies have been carried out by Hendon (1988) and Chen et al. (1989) on the relevance of linear models to the observed large-scale monsoon flow. The low-level flow is found to be consistent with the results of Matsuno (1966), Webster (1972) and Gill (1980) for the flow induced by a region of local heating in the tropics. Equatorially-trapped Rossby modes produce low-level westerlies to the west of the region of large-scale latent heat release, while an equatorial Kelvin mode is generated to the east producing low-level easterlies (as observed in the central tropical Pacific region).

Analysis of the mean low-level and upper-level flow fields, however, raises doubts about the validity of the common assumption of zero depth-averaged 
mass flux in the tropics; i.e. a first-order vertical mode approximation. Hendon et al. (1989) use three-year averages from the BMRC tropical analysis system to show that the $200-\mathrm{hPa}$ flow is not simply the reverse of the $850-\mathrm{hPa}$ flow, except in the vicinity of the monsoon shear line. Thus the upper-level flow is approximately symmetric about the equator (suggesting that the main heat source is on the equator), while the low-level flow corresponds to the Gill (1980) solution with a dominant heat source over the southern hemisphere tropics, north of Australia. It is unlikely that this discrepancy indicates an inconsistency in the BMRC tropical analysis system. On the other hand, it does suggest that the linear theory applies only in regions dominated by diabatic heating. The difference between the large scale dynamics at upper and lower levels is studied by Sardeshmukh and Hoskins (1985) in a diagnostic analysis of the mean vorticity balance, derived from ECMWF objective analyses. They show that the low-level balance is essentially linear (as assumed by Gill) whereas at upper levels, where the mean zonal flow is stronger, the large scale vorticity budget is dominated by a nonlinear balance between the stretching and advection of absolute vorticity by the time-mean horizontal flow.

The symmetric response at upper levels implies that the equatorial easterlies undergo a semi-annual oscillation with the maxima coinciding with the peak convective activity in the northern and southern hemisphere summer monsoons. This double peak is observed in the three-year averages of tropical analyses by Hendon et al. (1989).

There has been some recent analysis of the nature of the synoptic-scale weather systems embedded in the monsoon flow. Mapes and Houze (1991) show that the mesoscale convective systems in AMEX influence the synoptic-scale, particularly through their tendency to increase the large-scale vorticity. Detailed studies of two monsoon depressions by Davidson and Holland (1987) suggest that their structure and dynamics are almost identical to those in tropical cyclones. Diagnostic studies of the development and evolution of tropical cyclones that occurred during AMEX (Davidson et al., 1990) indicate the role of downstream Rossby-wave dispersion in cyclogenesis and the importance of interaction between a cyclone and the large-scale sub-tropical flow in the upper troposphere. Numerical modelling studies of a tropical cyclone during AMEX by Davidson and Kumar (1990) show that its structure can be simulated accurately, but the simulation is sensitive to the initial wind and moisture fields. Davidson and Puri (1991) find that these fields can be better represented through the use of satellite-derived bogus moisture profiles and bogus wind data for the tropical cyclone structure.

Sumner and Bonnell (1986) find that the inten- sity and distribution of rainfall in north-eastern Australia are related to the type of synoptic system associated with it, particularly the monsoon trough, tropical cyclones, depressions, and ridging along the east coast. Further studies of Australian monsoon rainfall by Jackson $(1986,1988)$ demonstrate that the daily rainfall has a higher intraseasonal variability than in other monsoon regions. Indeed the variability is similar to that in central Africa. The high intraseasonal variability of rainfall in the Australian tropics is consistent with the welldocumented large interannual variability of Australian rainfall (Nicholls, 1988).

\section{Interannual variability}

Holland (1986) shows that the duration of the Australian monsoon is very variable, with a mean duration of 74 days and a standard deviation of 25 days. Similarly the date of monsoon onset has a standard deviation of 15 days. As indicated by Jackson $(1986,1988)$, the monsoon rainfall is marked by a relatively small number of major events each season. Thus there is little relationship between the monsoon duration and total rainfall (Nicholls et al., 1982). Moreover there is not a strong correlation between features of the monsoon and the Southern Oscillation Index (SOI), which generally relates highly with Australian rainfall (McBride \& Nicholls, 1983).

Holland (1986) does find a significant correlation of 0.5 between the SOI and the rainfall over northern Australia in the monsoon season. He suggests that this difference from McBride and Nicholls (1983) arises from the different mean rainfalls used. (He takes the mean over the monsoon season and over all of northern Australia, while McBride and Nicholls use the seasonal mean of December to February over a number of sub-areas.) However, recent analysis of SOI relationships in the Australian region by Drosdowsky and Williams (1991) implies that the difference may reflect uncertainties in the robustness of the correlation. Using the period 1950-87, they find relatively high correlations of the SOI with summer rainfall across northern Australia. The low correlations of McBride and Nicholls are computed from the period 1932-74. For the decade of the 1930s, climate correlations with the SOI were irregular, and data sets using that period tend to have much weaker correlations than those that do not.

Although regional aspects of the monsoon have relatively weak relationships to the SOI, it is apparent that the large-scale flow is influenced by the Southern Oscillation. During years of an El NinoSouthern Oscillation (ENSO) event, convection is suppressed over the maritime continent and the centre of convection (as indicated by the OLR field) moves eastward towards the date-line. During antiENSO years the convection of the maritime continent is enhanced. An example of the differences 
between regional and large-scale behaviour arose during AMEX, which occurred at the time of a weak ENSO. The ENSO event was associated with a drought in north-eastern Australia, yet over 800 $\mathrm{mm}$ of rain fell in the region near Darwin during the 36 days of AMEX.

Drosdowsky and Williams (1991) confirm the observation of McBride and Nicholls (1983) that rainfall in northern Australia in the transition season (September to November) is highly correlated to the SOI. It is therefore consistent that the date of monsoon onset is found to be correlated to the SOI in that season (Holland, 1986; Joseph et al., 1991). In fact the onset date is more highly correlated to the SOI in the following year, and so an early monsoon onset could be used to predict an ENSO event in the following year (Holland, 1986).

\section{Monsoon onset}

Troup (1961) shows that the onset of the Australian monsoon season is marked by distinct changes in the upper winds and rainfall near Darwin. Nicholls (1984) confirms that a consistent estimate of onset of the wet season can be obtained from the date at which the cumulative rainfall exceeds a specified threshold. This date of onset of the wet season is related to the date of onset of the monsoon determined from the large-scale circulation changes. The relationship arises because the monsoon onset tends to be sudden and widespread (Hendon and Liebmann, 1990a).

Holland (1986) defines the monsoon onset in terms of the sign of the mean $850-\mathrm{hPa}$ zonal wind at Darwin. He fits a cubic spline through daily-mean upper air data over the period October through to September, and takes onset to occur when the filtered $850-\mathrm{hPa}$ wind first becomes westerly. This onset date has a significant correlation of 0.49 with the wet-season onset date of Nicholls (1984).

Hendon and Liebmann (1990a) consider an onset date that explicitly ensures that the wind change is accompanied by enhanced rainfall. Following Holland (1986), they use the daily-mean zonal wind at Darwin as the primary indicator of onset, but they impose the additional constraint that the rainfall at onset must be greater than $7.5 \mathrm{~mm} /$ day averaged over all stations north of $15 \mathrm{~S}$. Thus their onset is at the first occurrence of wet westerly conditions.

Holland (1986) finds the mean onset date is 24 December with a standard deviation of 15 days, while Hendon and Liebmann (1990a) obtain values of 25 December and 16 days. Although their average results are similar, the onset dates for specific years are sometimes found to vary significantly. One reason for the different onset dates is the exclusion of a rainfall criterion by Holland. However, a further reason for discrepancies is the different methods of filtering the wind data at Darwin; Holland uses a cubic spline while Hendon and Liebmann take a running mean. The sensitivity of the onset date to the method of computation implies that it is not feasible to attempt to define the date with a precision greater than a few days. We note that by defining onset in terms of a lagged running mean of the Darwin $850-\mathrm{hPa}$ wind it would be possible to specify the date in real time, rather than as a diagnostic after the end of the wet season.

In order to clarify the structure of the monsoon onset, Hendon and Liebmann (1990a) construct 40day composites of various fields centred on the onset date. They generally average over 30 years of data from 1957-1987. The composites strongly confirm the initial results of Troup (1961) that onset occurs rapidly over an interval of 5 to 10 days, with the subtropical jet moving poleward and the upper-level easterlies expanding symmetrically about the equator. These changes are associated with a southward shift in the Hadley circulation and development of an upper-level anticyclone over north Australia, as shown previously by Davidson et al. (1983, 1984).

Using similar composites of OLR data (averaged over 12 years), Hendon and Liebmann (1990a) demonstrate that the monsoon onset occurs with the eastward propagation of a large-scale region of convection. In the composite average, the convective region can be identified in the Indian Ocean up to 20 days before onset, and it propagates with a speed of about $5 \mathrm{~m} / \mathrm{s}$. Although the areas of positive OLR anomaly move steadily, the region of enhanced convection (negative OLR anomaly) is found to slow for about 10 days over Australian longitudes, suggesting an interaction between the propagating system and the stationary monsoon forcing of the continent. Further research is required to determine the interannual variability about this composite structure and to consider the feasibility of prediction of monsoon onset.

Hendon and Liebmann (1990a) suggest that the monsoon onset is linked to the 40-50 day oscillation of Madden and Julian (1972). As the 40-50 day wave moves eastward, the region of convection expands southward over the Australian continent, and then it retreats northward as the wave continues eastward. Earlier analysis by Davidson et al. (1983) suggests that the southward movement of the monsoon shear line is related to midlatitude interactions. Taking six case studies, they find that the onset is preceded by a westerly trough extending to $10 \mathrm{~S}$ over southwestern Australia and interrupting the subtropical ridge. The monsoon onset then occurs following some days of ridging over southwestern Australia. McBride (1987) points out that this midlatitude interaction should be seen as at most a necessary condition (or trigger) rather than a sufficient condition for monsoon onset, which depends mainly on the large-scale conditioning of the tropical 
troposphere.

The role of midlatitude interactions on monsoon onset has not been clarified by current analyses of the AMEX data set. The analysis of Hendon et al. (1989) implies that, because AMEX took place at a time of an ENSO event, the onset was somewhat anomalous. The onset date was very late at 14 January, consistent with an ENSO year. In the month prior to the monsoon, ENSO-related anomalous convection and low-latitude surface westerlies were present over the central Pacific. This upward motion brought about subsidence over Australian longitudes, thus inhibiting the monsoon onset. The westerlies in the western Pacific persisted from November to January, but they declined shortly before the monsoon onset. Hendon et al. suggest that the reduction in convection in the western Pacific relieved the subsidence over northern Australia, and so the monsoon could be triggered by the passage of the next burst of eastward-moving convection.

While the hypothesis of Hendon et al. (1989) is feasible for the anomalous monsoon of 1986-87, most evidence implies that the genesis of the monsoon is usually found to the west of Australia. For example, the composite study of Hendon and Liebmann (1990a) shows that it is generally associated with the passage of the 40-50 day oscillation. On the other hand, the studies of Davidson et al. (1983, 1984) indicate that mid-latitude events in the southern hemisphere play a substantial role in triggering the monsoon. The relationship between these various forcing mechanisms is one of the more important topics for further research.

The AMEX data set is particularly useful for numerical-modelling studies of the monsoon onset. The intensive observations commenced on 10 January 1987, four days before the monsoon onset at Darwin. Puri (1990) and Puri et al. (1991) show that the onset can be predicted 24 hours (but not 48 hours) ahead using both the ECMWF global model and the BMRC tropical numerical weather prediction model. The initialization and parameterization of diabatic heating is the primary problem for modelling the onset.

\section{Intraseasonal variability}

Troup (1961) notes the intermittent nature of the Australian monsoon, which generally involves a series of bursts of extensive rainfall and westerly winds. It is apparent that the active-break cycle of the monsoon is linked to the 40-50 day oscillation of Madden and Julian (1972). Using a Butterworth filter with a peak response at a period of 45 days, McBride (1987) shows that the zonal wind at Darwin has a large amplitude oscillation at 100 $\mathrm{hPa}$ throughout the year. On the other hand, the filtered zonal wind at $850 \mathrm{hPa}$ has a significant amplitude only during the monsoon season. At those times, the $100-\mathrm{hPa}$ and $850-\mathrm{hPa}$ winds are coherent and in anti-phase. Both the spectral peak in the low-level zonal wind and the vertical coherence of the zonal wind at Darwin during the monsoon are confirmed through spectral analysis by Madden (1986) and Hendon and Liebmann (1990b). However, Madden finds that the spectra of the monsoon upper-level winds do not differ significantly from red noise.

The link between the intraseasonal variability of the monsoon and the 40-50 day oscillation is confirmed by a detailed composite analysis of Hendon and Liebmann (1990b). Their primary data are the daily $850-\mathrm{hPa}$ zonal wind and the daily rainfall over northern Australia, processed with a 30-60 day bandpass filter. By defining an active event as an interval containing a peak in both the wind and rainfall data, they obtain 91 events over the 30-year period from 1957 to 1987 . Composites are constructed by averaging over all the events for a 40 -day period centred at the time of maximum $850-\mathrm{hPa}$ wind.

The composite time-height fields of wind, temperature and moisture clearly demonstrate that an active event can be approximated by a first-ordermode disturbance with upper-level easterlies and low-level westerlies. Similarly the meridional wind disturbance is consistent with a transient poleward shift in the Hadley circulation. The temperature and moisture fields show the event generally to warm and moisten the troposphere, particularly at the time of peak rainfall. Evaporation of precipitation in the lower atmosphere leads to a cool anomaly below $850 \mathrm{hPa}$, while the convection causes the warm anomaly to extend to $100 \mathrm{hPa}$.

Analysis of OLR data over the last few years has led to increased understanding of the regional structure of convection in the tropics. Hendon and Liebmann (1990b) take OLR composites for 35 of their active monsoon events, and show that there is convection over all the Australian tropics at the time of peak rainfall in the composite event. The convection even extends to south-eastern Australia and there is suppressed convection in the Indian Ocean south of the equator.

Hendon and Liebmann (1990b) find that the region of enhanced convection extends over about 60 degrees of longitude, and that it propagates eastward at a speed of $4-5 \mathrm{~m} / \mathrm{s}$. The $40-50$ day nature of the events therefore comes not from their propagation (as they would take 80-90 days to circle the globe) but from their distinct 30-day lifetime.

It is apparent that the monsoon convection contains a variety of fluctuations, not just the 40-50 day oscillation. Hendon and Liebmann (1990b) find that the rainfall spectrum does not have a significant peak at the 40-50 day period. On the other hand, it is a red spectrum, exhibiting high coherence with the $850-\mathrm{hPa}$ wind at Darwin at all periods greater 
than about 30 days. There is little coherence between rainfall and zonal wind at periods less than 20 days. This result emphasises the earlier suggestion that, while the large-scale structure of the monsoon is related to external influences such as the Southern Oscillation, there is a range of regional sources of intraseasonal fluctuations in the monsoon.

Analysis of FGGE data has led to the suggestions that these regional sources could be cross-equatorial surges in the northern hemisphere trades (Murakami and Sumi, 1982; Lim and Chang, 1981) or surges in a low-level southerly jet off the west coast of Australia (Davidson et al., 1983, 1984). Wang and Murakami (1987) find that both these high-frequency surges act to enhance convection rather than to trigger it. Indeed they suggest that only the low-frequency (40-50 day) component of the southerly surges from the Indian Ocean are associated with the initiation of convection, consistent with the results of Hendon and Liebmann (1990b). Comparison of results on surges is made difficult by substantial inconsistencies between definitions of the dates of occurrence of surges, but Keenan and Brody (1988) confirm the results of Wang and Murakami that westerly surges tend only to vary the local intensity of the monsoon convection. Using composite analyses, Keenan and Brody find that the regional convection is preceded by one to two days by the protrusion of an upperlevel mid-latitude trough into the tropics. On the other hand, Davidson and Hendon (1989) propose that the movement of this regional convection is due to energy dispersion of equatorially-trapped Rossby waves in a westerly mean flow.

The monsoon shear line, which lies across northern Australia during the monsoon, is itself a source of intraseasonal variation. Tropical cyclones can generate near it, and their presence or absence affects the structure of the monsoon circulation (McBride, 1986). Mapes and Houze (1991) describe how the active-break cycle of the monsoon system during AMEX consisted of the spin-up and subsequent dissipation of tropical cyclones.

There are clearly many local sources of intraseasonal variability in the monsoon. Thus the studies of McBride (1987) and Hendon et al. (1989) show that both eastward and westward moving disturbances occur in the regions of large-scale convection. Synthesis of the various studies that have been carried out over the last few years on the different types of convection associated with the Australian monsoon suggest that there is a hierarchy of interacting scales (Lau et al., 1991). On the largest (wavenumber one) scale, the 40-50 day oscillation described by Hendon and Liebmann (1990b) conditions the maritime continent for convective activity on a 40-50 day period. It is quasi-stationary, but it incorporates a slow eastward movement during its active cycle, as described above.
Embedded within the planetary-scale region of convection, there exist "super clusters" which have a scale of two to three thousand kilometres. Most studies of this scale have focused on convection in the equatorial western Pacific during the northern hemisphere summer (Nakazawa, 1986, 1988; Hayashi and Nakazawa, 1989; Takayuba and Murakami, 1991). In that region the super clusters generally move eastward at speeds of 10-15 $\mathrm{m} / \mathrm{s}$. In the Australian monsoon, the super-cluster scale of convective organization has been studied by McBride (1983), Keenan and Brody (1988) and Hendon et al. (1989). Here the super clusters are observed to move both eastward and westward with phase speeds closer to $5-10 \mathrm{~m} / \mathrm{s}$.

Embedded within a super cluster are smaller cloud clusters with space scales of $100-500 \mathrm{~km}$ and durations of 1-3 days. Studies of these systems in the equatorial Pacific and northern-hemisphere summer suggest that the systems propagate westward through their parent super cluster (Nakazawa, 1988; Lau et al., 1991). It is not apparent, however, that this characteristic is dominant in the Australian monsoon. Indeed McBride and Keenan (1982) report that pre-tropical-cyclone cloud clusters further south on the monsoon shear line move slowly in either longitudinal direction. It is noted, however, that the Nakazawa-type Hovmoeller analysis of OLR on the 3-hours to several-days time scale has not been carried out for the southern monsoon.

In summary, the convection associated with intraseasonal fluctuations of the Australian monsoon involves scales extending from the planetary to the mesoscale, and interactions between these features have not been fully documented or explained.

\section{Mesoscale structure}

Since 1986 there has been a succession of field studies in northern Australia which have demonstrated the richness of the mesoscale structure of the systems within the monsoon. The first of these experiments was AMEX, prior to which the main source of detailed data on tropical convection had been that from the GARP Atlantic Tropical Experiment (GATE). However, the persistence of the monsoon during AMEX meant that a number of intense cloud clusters formed within the primary AMEX upper-air array.

Frank and McBride (1989) and McBride and Frank (1991) carry out budget studies of the vertical heating profile associated with these cloud clusters. Comparison of the gross structure of cloud clusters from GATE and AMEX shows that they have similar life-cycles, except that the peak rainfall in AMEX is about $25 \%$ larger. This difference can be explained by the warmer sea-surface temperature and the moister monsoon conditions of AMEX. The evolution of the profile of mean vertical velocity in 
the cloud clusters is quite different, however, because the AMEX systems exhibit heating maxima in the middle troposphere with the level of maximum heating varying little in time. In contrast, the GATE systems exhibit significantly more heating at lower levels and an upward shift of heating with time during their lifecycles. McBride and Frank (1991) suggest these differences may result from GATE being drier at middle levels, resulting in larger middlelevel detrainment so that the heating occurs lower during the early stages of the cloud-cluster lifecycle. They also note the differences in large-scale vertical velocity in the two regions, and hypothesise that stronger and deeper convergence in the AMEX region relative to GATE causes more rapid formation of stratiform rain (and hence heating at higher levels) in the Australian monsoon region.

The data from AMEX also provide further information on the range of diurnal variations in the mesoscale features of the monsoon. Analysis of GMS infrared and weather radar data by Keenan et al. (1989a) shows that the amplitude of diurnal fluctuations over the land during AMEX is much larger than that over the maritime areas. There are also phase differences between land and ocean convection, with peak convection over the land at about 1530 LST and over the sea in the early morning. The area-averaged vertical velocity field during AMEX is found to be consistent with the direct measures of convective activity. The diurnal variations over the sea are relatively weak, with a peak at $500 \mathrm{hPa}$ in the early morning. The vertical velocity over the land has a large maximum in the afternoon at about $400 \mathrm{hPa}$, and there is subsidence in the early morning. As with analyses of GATE data (e.g. McBride and Gray, 1980; Albright et al., 1981), the time of peak vertical motion is found in AMEX to vary with the strength of the convection; i.e. differences occur between suppressed and enhanced convective conditions. However, the actual times of peak ascent are not the same for GATE and AMEX. These differences are probably due to the different synoptic conditions prevailing for the two experiments, but further study is required to clarify the cause.

Analyses of the organization and structure of mesoscale systems during AMEX have been carried out by Churchill and Houze (1991) and Mapes and Houze (1991). They find that a necessary condition for the existence of convection over a region is that the precipitable water must be greater than $50 \mathrm{~mm}$. They also find that the main controlling parameters are the low-level and upper-level shears. Low boundary-layer shear leads to scattered convection embedded in regions of stratiform precipitation, while a high shear is associated with line convection in which there is more convective than stratiform rain. The upper-level shear influences the nature of the stratiform cloud, such that high shear tends to fragment the stratiform regions. The form of the convection is shown to be closely related to the prevailing synoptic conditions, suggesting that parameterization should be possible.

Since AMEX there has been a number of mesoscale studies of convection near Darwin, based on Doppler radar observations and associated measurements of surface weather conditions (Keenan et al., 1988; 1989b). Keenan and Carbone (1992) provide a morphology of the range of convective systems that occur near Darwin during both active and break periods of the monsoon. Their results are consistent with those of Churchill and Houze (1991) in the sense that the $700-\mathrm{hPa}$ wind is found to be a determining factor in the behaviour of storms, but they also use the Doppler radar to examine the detailed mesoscale structure. The convection in active monsoon periods is generally weak, but it can develop squall-like storms that propagate eastward. The convection can have moderate values of convective available potential energy (CAPE) and it is embedded in rather shallow boundary-layer shear. Keenan and Rutledge (1991) use dual-Doppler radar data to describe the evolution of a monsoon rainband in conditions of low shear and CAPE.

In the break periods (or in the transition season before the monsoon onset), a wide variety of storms occurs with the main control being the structure of the $700-\mathrm{hPa}$ easterly wind maximum. The types of storm include continental thunderstorms, sea-breeze initiated storms, island thunderstorms, and westward moving squalls.

The island thunderstorms develop over Bathurst and Melville Islands to the north of Darwin, and they are representative of the storms that play a major role in mixing the troposphere over the whole maritime continent. Keenan et al. (1991a) present a climatology of these storms, showing that they appear on at least $65 \%$ of days in the transition season with moderately high values of CAPE and low values of shear.

The squall lines around Darwin are similar to those observed during GATE (Houze, 1977), but the Darwin storms occur in a wider range of shear and CAPE conditions. The squalls generally move with the steering-level flow, but faster and slower cases occur. The non-propagating or slow squalls appear with the largest values of the easterly jet, while the propagating or fast cases arise when the easterly jet is weak. Although the fast squalls tend to occur in more stable conditions, there is little sensitivity of the storm speed to the CAPE value (Keenan and Carbone, 1992). The squall lines tend to become oriented perpendicularly to the low-level wind shear. This behaviour is associated with the occurrence of flow into the rear of the storm, transporting momentum into the cold pool in the planetary boundary layer. The interaction of the cold pool with the en- 
vironment determines the structure and evolution of the convective system.

The structure of squall lines and mesoscale convective systems (MCSs) in the oceanic monsoon westerlies north of Australia was studied in ten multiple-aircraft research flights during EMEX. Mapes and Houze (1991) summarise these observations and note that the mesoscale structure consists of an ensemble of convective lines and stratiform regions, much like the tropical oceanic MCSs of GATE (Houze and Betts, 1981) and MONEX (Johnson and Houze, 1987). They find, however, that the various patterns of mesoscale structure depend upon the prevailing larger-scale wind field.

A common theme in the results of these northern Australia field studies has been the existence of two distinct convective regimes, associated respectively with monsoon conditions and break or transition season conditions. Rutledge et al. (1992) and Williams et al. (1990) show that the monsoon regime is characterised by very low values of CAPE and low lightning rates, whereas the break convection has high CAPE and high lightning rates. Extrapolating these results to the rest of the tropics, they propose that the deep convection which contributes to the global electrical circuit is mainly associated with break or tropical-continental conditions. Thus it occurs in a different regime from the monsoon-type convection, which is the main contributor of latent heat to the equatorial Hadley Cell.

Operational forecasting in the tropics has always been difficult, largely because of the importance of locally-generated mesoscale systems in a large-scale background of weak forcing. Short-term prediction is generally no more accurate than persistence or climatology (Holland et al., 1987). However, Fraedrich and Leslie (1988) show that prediction of tropical rainfall 12 hours ahead can be improved through the use of statistical Markov chain methods. The recent observations and analysis of the initiation and evolution of tropical mesoscale systems near Darwin should lead to better short-range predictions in the future. Towards this end, Keenan et al. (1991b) use Doppler radar and associated surface observations to demonstrate that subjective nowcasting of storm development can be more accurate than climatology for up to 2.5 hours ahead.

\section{Conclusions}

There has been a sustained research effort over the last few years on improving our understanding of all aspects of the Australian summer monsoon. Work on large-scale features has been aided by developments in numerical weather prediction, which make these products more reliable for diagnostic studies. Major gains are being found through the use of highresolution GMS infrared imagery to estimate the distribution of diabatic heating or convective activ- ity in the tropics.

Such diagnostic fields have been used particularly to study the onset and intraseasonal variations of the monsoon. Although the range of scales associated with these variations is recognized to extend from the planetary down to the cloud cluster, the strong interactions between them have not been clarified. Moreover, there has not been an agreed definition of active and break phases of the monsoon, because the precise day of transition is found to depend upon the type of filter employed on the data.

Analysis of the mesoscale features of the monsoon has been facilitated by a series of observational projects centred on Darwin over the last five years. The first series of these projects was the conjunction of AMEX, EMEX and STEP in January and February 1987, which yielded upper-air, aircraft and surface data on the onset and evolution of two active-break cycles of the monsoon. Since that time, a number of Doppler radar studies have been carried out on the structure of mesoscale convection throughout the monsoon season.

The intensive observations of the monsoon have been concentrated on northern Australia, i.e. on the structure south of about $10 \mathrm{~S}$. It would be desirable for future studies to consider more closely the behaviour of the monsoon nearer the equator. In particular, it is necessary to clarify the evolution of the monsoon over the Indonesian archipelago and New Guinea.

\section{References}

Albright, M.D., D.R. Mock, E.E. Recker and R.J. Reed, 1981: A diagnostic study of the diurnal rainfall variation in the GATE B-scale area. J. Atmos. Sci., 38, $1429-1445$.

Berson, F.A., 1961: Circulation and energy balance in a tropical monsoon. Tellus, 13, 472-485.

Chen, T.-C., M.-C. Yen, and H. Van Loon, 1989: The effect of the divergent circulation on some aspects of the 1978/79 southern hemisphere monsoon. J. Climate, 2, 1270-1288.

Churchill, D.D. and R.A. Houze, 1991: Mesoscale convective systems and large-scale flow near Darwin Australia during the Australian Monsoon Experiment. Mon. Wea. Rev., (submitted).

Davidson, N.E. and H.H. Hendon, 1989: Downstream development in the Southern Hemisphere monsoon during FGGE/WMONEX. Mon. Wea. Rev., 117, 1458-1470.

Davidson, N.E. and G.J. Holland, 1987: A diagnostic analysis of two intense monsoon depressions over Australia. Mon. Wea. Rev., 115, 380-392.

Davidson, N.E. and A. Kumar, 1990: Numerical simulation of the development of AMEX tropical cyclone Irma. Mon. Wea. Rev., 118, 2001-2019.

Davidson, N.E. and K. Puri, 1991: Tropical prediction using dynamical nudging. Satellite-defined convective heat sources and a cyclone bogus. Mon. Wea. Rev., (submitted). 
Davidson, N.E., J.L. McBride and B.J. McAvaney, 1983: The onset of the Australian monsoon during winter MONEX: Synoptic aspects. Mon. Wea. Rev., 111, 496-516.

Davidson, N.E., J.L. McBride and B.J. McAvaney, 1984: Divergent circulations during the onset of the 197879 Australian Monsoon. Mon. Wea. Rev., 112, 1684-1696.

Davidson, N.E., G.J. Holland, J.L. McBride and T.D. Keenan, 1990: On the formation of AMEX tropical cyclones Irma and Jason. Mon. Wea. Rev., 118, 1981-2000.

Drosdowsky, W. and M. Williams, 1991: The southern oscillation in the Australian region. Part I: anomalies at the extremes of the oscillation. J. Climate, 4, 619638 .

Fraedrich, K. and L.M. Leslie, 1988: Real-time shortterm forecasting of precipitation at an Australian tropical station. Weath. Forecast, 3, 104-114.

Frank, W.M. and J.L. McBride, 1989 The vertical distribution of heating in AMEX and GATE cloud clusters. J. Atmos. Sci., 46, 3464-3478.

Gill, A.E., 1980: Some simple solutions for heat induced tropical circulation. Quart. J. Roy. Meteor. Soc., 106, 447-462.

Gunn, B.W., J.L. McBride, G.J. Holland, T.D. Keenan and N.E. Davidson. 1989: The Australian summer monsoon circulation during AMEX Phase II. Mon. Wea. Rev., 117, 2554-2574.

Hayashi, Y.-K. and T. Nakazawa, 1989: Evidence of the existence and eastward motion of superclusters at the equator. Mon. Wea. Rev., 117, 236-243.

Hendon, H.H., 1988: A qualitative assessment of the Australian tropical region analyses. Mon. Wea. Rev., 116, 5-17.

Hendon, H.H. and B. Liebmann, 1990a: A composite study of onset of the Australian Summer monsoon. J. Atmos. Sci., 47, 2227-2240.

Hendon, H.H. and B. Liebmann, 1990b: The intraseasonal (30-50 day) oscillation of the Australian Summer monsoon. J. Atmos. Sci., 47, 2909-2923.

Hendon, H.H., N.E. Davidson and B. Gunn, 1989: Australian summer monsoon onset during AMEX 1987. Mon. Wea. Rev., 117, 370-390.

Holland, G.J., 1986: Interannual variability of the Australian summer monsoon at Darwin: 1952/82. Mon. Wea. Rev., 114, 594-604.

Holland, G.J., L.M. Leslie, K. Fraedrich and G.B. Love, 1987: The challenge of very short range forecasting in the tropics. ESA SP-282, 287-295.

Houze, R.A. Jr., 1977: Structure and dynamics of a tropical squall-line system. Mon. Wea. Rev., 105, 15401567.

Houze, R.A. Jr. and A.K. Betts, 1981: Convection in GATE. Rev. Geophys. Space Phys., 19, 541-604.

Hunt, H.A., G. Taylor and E.T. Quayle, 1913: The climate and weather of Australia, Government Printer, Melbourne. Australia.

Jackson, I.J., 1986: Relationships between raindays, mean daily intensity and monthly rainfall in the tropics. J. Climatol., 6, 117-134.

Jackson, I.J., 1988: Daily rainfall over Northern Australia: deviations from the world pattern. J. Clima- tol., 8, 463-476.

Johnson, R.H. and R.A. Houze, Jr., 1987: Precipitating cloud systems of the Asian monsoon. Monsoon Meteorology. C.P. Cheng and T.N. Krishnamurti, Eds., Oxford University Press, 298-353.

Joseph, P.V., B. Liebmann and H.H. Hendon, 1991: Interannual variability of the Australian summer monsoon onset: possible influence of Indian summer monsoon and El Niño. J. Climate, 4, 529-538.

Keenan, T.D. and L.R. Brody, 1988: Synoptic-scale modulation of convection during the Australian summer monsoon. Mon. Wea. Rev., 116, 71-85.

Keenan, T.D. and R.E. Carbone, 1992: A preliminary morphology of precipitation systems in tropical northern Australia. Quart. J. Roy. Meteor. Soc., (in press).

Keenan, T.D., G.J. Holland, M.J. Manton and J. Simpson, 1988: TRMM ground truth in a monsoon environment: Darwin, Australia. Aust. Meteor. Mag., 36, 81-90.

Keenan, T.D., J.L. McBride, G.J. Holland, N.E. Davidson and B. Gunn, 1989a: Diurnal variations during the Australian Monsoon Experiment (AMEX) Phase II. Mon. Wea. Rev., 117, 2535-2552.

Keenan, T.D., B.R. Morton, M.J. Manton and G.J. Holland, 1989b: The Island Thunderstorm Experiment (ITEX)-A study of tropical thunderstorms in the Maritime Continent. Bull. Amer. Met. Soc., 70, 152-159.

Keenan, T.D., B.R. Morton, S.Z. Xu and K. Nyguen, 1991a: A climatology of tropical island thunderstorms over Bathurst and Melville Islands near Darwin Australia. Quart. J. Roy. Meteor. Soc., 116, 1153-1172.

Keenan, T.D., R.J. Potts and J. Wilson, 1991b: The Darwin mesoscale and nowcasting experiment: Description and preliminary results. Aust. Meteor. Mag., 39, 211-222.

Keenan, T.D. and S.A. Rutledge, 1991: Mesoscale characteristics of monsoonal convection and associated stratiform precipitation. Mon. Wea. Rev., (submitted).

Kiladis, G.N., H. Von Storch and H. Van Loon, 1989: Origin of the South Pacific convergence zone. J. Climate, 2, 1173-1184.

Lau, K.M., T. Nakazawa and C.H. Sui, 1991: Observations of cloud cluster hierarchies over the tropical western Pacific. J. Geophys. Res., 96, 3197-3208.

Lim, H. and C.P. Chang, 1981: A theory for midlatitude forcing of tropical motion during the winter monsoon. J. Atmos. Sci., 38, 2377-2392.

Madden, R.A., 1986: Seasonal variation of the 40-50 day oscillation in the tropics. J. Atmos. Sci., 43, 3138-3158.

Madden, R.A. and P.R. Julian, 1972: Description of global-scale circulation cells in the tropics with a 40 50 day period. J. Atmos. Sci., 29, 1109-1123.

Maher, J.V. and D.M. Lee, 1977: Upper air statistics, Australia, surface to $5 \mathrm{mb}, 1957$ to 1975 , Meteor. Summary, Bureau of Met., PO. Box 1289K, Melb, Vic 3001 Australia, 200 pp.

Mapes, B. and R.A. Houze, Jr., 1991: An integrated view of the 1987 Australian monsoon and 
its mesoscale convective systems. Part I: Horizontal structure. Quart. J. Roy. Meteor. Soc., (submitted).

Matsuno, T., 1966: Quasi-geostrophic motions in the equatorial area. J. Metor. Soc. Japan, 44, 25-43.

McBride, J.L., 1983: Satellite observations of the southern hemisphere monsoon during winter MONEX. Tellus, 35A, 189-197.

McBride, J.L., 1986: Tropical cyclones in the Southern Hemisphere summer monsoon. Extended Abstracts, Second International Conference on Southern Hemisphere Meteorology, December 1-5 1986, Wellington New Zealand, American Meteorological Society, Boston., 358-364.

McBride, J.L., 1987: The Australian summer monsoon. Reviews of Monsoon Meteorology, C.P. Chang and T.N. Krishnamurti, Eds., Oxford University Press, 203-231.

McBride, J.L. and W.M. Frank, 1991: Vertical profiles of cumulonimbus heating and drying in the tropics. Preprint Volume, 19th Conference on Hurricanes and Tropical Meteorology, American Meteorological Society, Boston, Ma. USA., 220-225.

McBride, J.L. and W.M. Gray, 1980: Mass divergence in tropical weather systems Paper I: Diurnal variation. Quart. J. Roy. Meteor. Soc., 106, 501-516.

McBride, J.L. and T.D. Keenan, 1982: Climatology of tropical cyclone genesis in the Australian region. $J$. Climat., 2, 13-33.

McBride, J.L. and N. Nicholls, 1983: Seasonal relationships between Australian rainfall and the Southern Oscillation. Mon. Wea. Rev., 111, 1998-2004.

McBride, J.L. and G.J. Holland, 1989: The Australian monsoon experiment (AMEX): Early results. Aust. Meteor. Mag., 37, 23-35.

Meehl, G.A., 1987: The annual cycle and interannual variability in the tropical Pacific and Indian Ocean regions. Mon. Wea. Rev., 115, 27-50.

Murakami, T. and A. Sumi, 1982: Southern hemisphere monsoon circulation during the 1978-79 WMONEX. 'Part I: Monthly mean wind fields. J. Meteor. Soc. Japan, 60, 638-648.

Nakazawa, T., 1986: Intraseasonal variations of OLR in the tropics during the FGGE year. J. Meteor. Soc. Japan, 64, 17-34.

Nakazawa, T., 1988: Tropical super clusters within intraseasonal variations over the Western Pacific. $J$. Meteor. Soc. Japan, 66, 823-839.

Nicholls, N., 1984: A system for predicting the onset of the north Australian wet season. J. Climatol., 4, $425-436$

Nicholls, N., 1988: El Nino-Southern Oscillation and rainfall variability. J. Clim. Appl. Meteor., 1, 418421.

Nicholls, N., J.L. McBride and R.J. Ormerod, 1982: On predicting the onset of the Australian wet season at Darwin. Mon. Wea. Rev., 110, 14-17.

Puri, K., 1990: Tropical numerical weather prediction studies for the 1987 Australian summer monsoon. Mausam, 41, 2, 257-264.

Puri, K., N.E. Davidson, L.M. Leslie and L.W. Logan, 1991: The BMRC tropical limited area model. Aust. Meteor. Mag., (submitted).
Rutledge S.A., E.R. Williams and T.D. Keenan, 1992: The Down Under Doppler and Electricity Experiment (DUNDEE): Overview and preliminary results. Bull. Amer. Meteor. Soc., (in press).

Sardeshmukh, P.D. and B.J. Hoskins, 1985: Vorticity balances in the tropics during the 1982-83 El NinoSouthern Oscillation event. Quart. J. Roy. Meteor. Soc., 111, 261-278.

Sikka, D.R. and S. Gadgil, 1980: On the maximum cloud zone and the ITCZ over Indian longitudes during the southwest monsoon. Mon. Wea. Rev., 108, 18401853.

Sumner, G. and M. Bonnell, 1986: Circulation and daily rainfall in the north Queensland wet seasons 19791982. J. Climatol., 6, 531-549.

Takayuba, Y.K. and M. Murakami, 1991: The structure of super cloud clusters observed in 1-20 June 1986 and their relationship to easterly waves. J. Meteor. Soc. Japan, 69, 105-125.

Troup, A.J., 1961: Variations in upper tropospheric flow associated with the onset of the Australian summer monsoon. Indian. J. Meteor. Geophys., 12, 217-230.

Wang, X.L. and T. Murakami, 1987: Intraseasonal meridional surges and equatorial convections during the southern hemisphere summer. J. Meteor. Soc. Japan, 65, 727-735.

Webster, P.J., 1972: Response of the tropical atmosphere to local, steady forcing. Mon. Wea. Rev., 100, 518-541.

Webster, P.J. and R.A. Houze, Jr., 1991: The equatorial mesoscale experiment (EMEX): an overview. Bull. Amer. Soc., 72, 1481-1505.

Williams, E.R., S.G. Geotis, N. Renno, S.A. Rutledge, E. Rasmussen and T. Rickenback, 1990: Preprint Volume, AMS Conference on Atmospheric Electricity, October 22-26 1990, Kananaskis Provincial Park, Alta, Canada. American Meteorological Society, Boston. 


\section{オーストラリア・モンスーンに関する最近の研究}

\section{M.J. Manton and J.L. McBride}

(Bureau of Meteorology Research Centre, Melbourne, Australia)

近年オーストラリア周辺熱帯域で行われたいくつかの観測実験から得られたデー夕によって、オースト ラリア・モンスーンに関する理解が大きく前進した。本論文では、モンスーンの大規模構造、年々変動、オ ンセット、季節内変動、メソスケール現象の構造等、最近の研究成果を紹介する。この期間、この分野に 関する研究は顕著な進展を見せたが、熱帯大気大循環とオーストラリア・モンンスーンとの関係等、今後 に残された課題も多い。 